Interdisciplinary Studies of Complex Systems

No. 15 (2019) 61-66

(c) Л. Савенкова

https://doi.org/10.31392/iscs.2019.15.061

\title{
ЕЛЕКТРОННІ ПУБЛІКАЦІї У СИСТЕМІ НАУКОВОї КОМУНІКАЦІї
}

\author{
Людмила Савенкова ${ }^{1}$
}

\begin{abstract}
Анотація. Важливим аспектом наукової діяльності є оприлюднення результатів досліджень та організація зберігання і доступу до джерел, що містять авторитетні дослідницькі матеріали. Традиційні форми життєвого циклу наукової публікації переживають виклики пов'язані з сучасним розвитком інформаційних технологій. Сучасні реалії існування наукових журналів бібліотек та архівів - це електронне середовище. Ініціативи Open Access (OA) викликали потребу у забезпеченні надійного і стійкого доступу до наукових журналів та публікацій і призвели до появи цілої низки різноманітних інструментів реєстрації, опису та обліку джерел.
\end{abstract}

\section{ELECTRONIC PUBLICATIONS IN THE SYSTEM OF RESEARCH COMMUNICATION}

\section{Liudmyla Savenkova}

\begin{abstract}
Publicizing the results of scientific researches, organizing of storage and access to the sources which include the authoritative research materials are known to be the most important aspects in scientific activity. Traditional forms the life- cycle of a scientific publication face to the challenges related to the modern development of information technology. Modern realities of existence of research journals, libraries and archives are the electronic environment. Initiatives of Open Access (OA) caused the need of ensuring reliable and sustainable access to scientific journals and publications and led to the emergence of a variety of tools of registration, description and accounting of sources.
\end{abstract}

Усі наукові відкриття і досягнення стають досягненнями тоді, коли вони оприлюднені, тоді, коли вони стають підгрунтям для нових досліджень. Розповсюджувати, опрацьовувати зберігати, надавати у користування інформацію про цивілізаційні надбання - завдання для інформаційних інституцій кожної країни. Не в останню чергу це стосується університетських видавництв, бібліотек, наукових архівів.

Традиційно, чільне місце у науковій комунікації посідає журнальна публікація. Наукові журнали називають серцем наукової комунікації.

\footnotetext{
${ }^{1}$ Національний педагогічний університет імені М.П. Драгоманова, Київ, Україна. lib-shef@npu.edu.ua, https://orcid.org/0000-0001-8889-4026.
} 
Від першого наукового журналу, що з'явився у 1665 році, понад 350 років це один з найважливіших, найбільш успішних і найбільш вдалих засобів поширення наукової інформації, критичного розгляду нових ідей, визначення напрямків наукових досліджень. Рецензовані журнали мають свої рейтинги, публікація в журналі з високим рейтингом може вплинути на відомість вченого, а проблема, яку він вирішує приверне загальну увагу та спонукає до обговорення. Саме за журнальними публікаціями оцінюють авторитет не лише ученого у світовій академічній громаді (індекс цитування), а й власне журналу - імпакт фактор [6].

Журнали, що готуються та видаються університетами, є частиною доволі великого пласту усіх наукових журналів. Пагубна тенденція останнього десятиліття - нівелювання наукового рецензованого журналу до задовільної збірки наукових статей з мінімальним виконанням формальних вимог, призвела до появи, так званих, «кишенькових» журналів, які не гребують статтями будь-якої якості за гроші автора, та можуть написати на сторінці з випускними даними, що не несуть відповідальності за те, що тут опубліковано. Розгубленість молодих науковців, іноді відсутність реального дослідження, нерозуміння сутності наукової новизни призводить до того, автори не розуміють причин відхилення поданої до рецензованого журналу статті: адже раніше до збірників брали все, варто було тільки написати, до повної картинки ще і переклад англійською виконаний за допомогою програмного забезпечення віднайденого у Інтернет.

Найбільше роздратування та розчарування відчувають представники гуманітарних наук, адже з цілої низки причин результати своїх досліджень вони не в змозі представити у високо рейтингових міжнародних журналах і це $є$ викликом для наукового життя сучасної України. Розвиток же власних авторитетних періодичних видань потребує значних ресурсів і часу. За даними представленими на Open Science in Ukraine (OSU) - проекті з комплексної підтримки наукових журналів в мережі Інтернет, лише 116 наукових журналів включено до міжнародних науко метричних баз даних [2]. У 2018 році Міністерством освіти і науки України видано наказ «Про затвердження Порядку формування Переліку наукових фахових видань України» Відповідно до цього Порядку до Переліку наукові фахові видання включаються за категоріями « $\mathrm{A} », ~ « », ~ « \mathrm{~B} »[5]$. За даними міністерства, на 11 липня 2019 року до категорії «А» віднесено 63 наукових періодичних видань, до категорії «Б» - 126, а до категорії «В» -1826 . Тобто, з близько двох тисяч зареєстрованих фахових видань лише 189 відповідно до вимог згаданого Порядку формування наближені до рівня міжнародних рецензованих журналів. На IX Науково-практичній конференції «Наукова періодика: традиції та інновації», що пройшла у червні 2019 року, О.Г Вакаренко зазначала, що «видання наукових журналів у спеціалізованому видавництві - це реальний шлях підвищення якості оприлюднення результатів наукових досліджень» [1]. Сучасні реалії існування наукових журналів - це електронне середовище. Залучення іноземних членів редакційних колегій, експертів, рецензентів, авторів, неможливо здійснити без інструментів електронної редакції, можливості забезпечення оперативного електронного документообігу, автоматизованого контролю за проходженням рукописів, без актуальної бази рецензентів тощо [1]. 
Електронне поширення інформації спричинило цілу низку змін у галузі наукової комунікації та появу нових економічних моделей функціонування наукових видань, а також тенденцій щодо відкритого доступу Open Accecs. Необмежений доступ до наукової літератури вважається необхідним для розширення і розвитку в області науки. Питання, пов'язані з обмеженнями, введеними традиційними передплатами, спонукали прагнення до альтернативних моделей журнальних публікацій і народження руху відкритого доступу. Видавнича модель Open Accecs розвивається, отримуючи підтримку від академічних та наукових кіл, наукових спонсорів, політиків і навіть традиційних видавців журналів. Низка дискусій охоплює виклики пов'язані з відкритим доступом до наукових досліджень: розвиток двох основних моделей Open Accecs - Green (самоархівування) Gold (оплата публікації автором), проблеми, пов'язані з якістю публікацій в журналах відкритого доступу, а також поява «грабіжницьких» журналів, які зловживають авторськими моделями АО [9].

Ініціативи Open Accecs (OA) широко підтримали університетські бібліотеки всього світу, адже саме бібліотекарі допомагають документувати дані про результати досліджень через оформлення метаданих. 3 метою забезпечення більш надійного і стійкого доступу до наукових журналів і публікацій з'являється і розвивається ціла низка різноманітних інструментів реєстрації, опису та обліку джерел. Серед них такі широко відомі як: міжнародний мультидисциплінарний каталог журналів відкритого доступу Directory of Open Access Journals (DOAJ), директорія інституційних та тематичних відкритих електронних архівів Directory of Open Access Repositories (OpenDOAR), бібліографічна база даних об'єднання видавців наукових публікацій, що зберігає інформацію про зв'язки публікацій через технологію Digital Object Identifier (CrossRef DOI), а також метадані опублікованих наукових матеріалів. У публікаціях науковців, що відображають результати досліджень з питань реалізації відкритого доступу у наукових комунікаціях, вказується на необхідність чутливості до змін в усіх сферах наукової інформації та комунікації, підтримуються стратегії відкритого доступу до ресурсів, які сприяють новій парадигмі у науковій комунікації, забезпечуючи переваги для науки і суспільства, а також підкреслюється роль бібліотеки, що застосовує різні способи і методи роботи 3 інформацією, у розвитку наукового знання $[7,8,9,10,11,12]$. В Україні до 2019 року з ініціативи університетських бібліотек створено понад 75 інституційних репозитарів, що власне є електронними архівами, призначеними для самоархівування наукових публікацій вчених університету. За визначенням Тетяни Ярошенко «репозитарій - організована колекція цифрових документів та набір сервісів навколо цієї колекції, яка репрезентує результати наукових досліджень (окремих дослідників, інституції чи галузі загалом) у вільному, безперешкодному онлайновому доступі, а також забезпечує довготривале, надійне їх зберігання і збереження»[7]. Україна, як і більшість країн світу, використовує для функціонування електронних архівів програмні продукти з відкритим кодом (DSpace, EPrint тощо). Організація та підтримка інституційних репозитаріїв не є унормованою роботою, тому вміст таких електронних колекцій може представляти набір різноманітних даних, що не мають чітко визначеної політики метаданих [8] 
та структурування фондів і колекцій - все залежить від місії та політики репозитарію. Сучасні дослідження підтверджують, що наявність публікацій у вільному мережевому доступі значно підвищує її видимість для наукової спільноти і показники цитувань за Google Scholar також мають місце [11] для ознайомлення з роботою окремих науковців.

Велика низка викликів чекає науковців, видавців, бібліотекарів стосовно можливостей цифрових наукових журналів та репозитаріїв відкритого доступу, перспектив впровадження Плану S, функціонування ліцензій Creative Commons тощо. Крім цілого пласту проблем, пов'язаних з вимогами комерційних видавництв та узгодженням авторських прав, фахівці зазначають і такі: відсутність мотивації у дослідників до додаткового розміщення в архівах своїх вже опублікованих робіт (хоча численні дослідження свідчать про значно більшу кількість завантажень для робіт з відкритого доступу, їх швидше і масштабніше поширення, але чи корелює це напряму з підвищенням цитування?), питання пов'язані з обсягами, якістю, сервісами для авторів чи користувачів, дизайном, використанням, надійністю, збереженням тощо [7]. Дискусійним також $є$ питання потреби оприлюднення у міжнародних виданнях результатів досліджень у суспільних та гуманітарних науках, присвячених регіональним тематикам, що друкуються різними мовами, а не лише англійською, адже публікаційна поведінка вчених у соціогуманітарних дисциплінах тісно пов'язана 3 культурною та історичною спадщиною країни [3].

Наукова спільнота завжди матиме потребу у комунікації, особливо 3 огляду на сучасні тенденції з одного боку конкретизації окремих робіт у визначеній галузі, з іншого - міждисциплінарності досліджень, а сучасний технологічний прогрес буде здійснювати дедалі більший вплив на появу нових варіантів і можливостей представлення результатів наукової роботи, з'являться нові проекти на кшталт проекту «Стаття майбутнього» (Article of the future) видавництва Elsevier, запропонованого ще у 2012 році.

\section{Література}

[1] Болкотун, 3.А., Радченко А.І. 2019. Науковий журнал - виклики сьогодення. IX Науково-практична конференція «Наукова періодика: традиції та інновації» Вісник НАН Украӥни 7:89-94. https://doi.org/ 10.15407/visn2019.07.089.

[2] Все украинские журналы в Scopus и Web of Science. Open Science in Ukraine (OSU). https://openscience.in.ua/ua-journals.

[3] Камінська, А. М., Назаровець С. А. 2018. Crossreff як джерело науко метричних даних для соціальних та гуманітарних наук. Сучасний стан наукових досліджень та технологій в промисловості. 3 (5):26-34. https://doi.org/10.30837/2522-9818.2018.5.026.

[4] Перелік наукових фахових видань України, в яких можуть публікуватися результати дисертаційних робіт на здобуття наукових ступенів доктора і кандидата наук (станом на 11 липня 2019 року) Наукові фахові видання. Міністерство освіти і науки України. https://mon.gov. ua/ua/nauka/nauka/atestaciya-kadriv-vishoyi-kvalifikaciyi/naukovi-faho vi-vidannya. 
[5] Про затвердження Порядку формування Переліку наукових фахових видань України Наказ МОН України від 15.01.2018, №32. https:// zakon.rada.gov.ua/laws/show/z0148-18.

[6] Ярошенко, Т.О. 2010. Електронні журнали в системі інформаційних ресурсів бібліотеки. Київ : Знання.

[7] Ярошенко Т. 2011. Зелений шлях відкритого доступу. Репозитарії таїх роль у науковій комунікації: перші двадџять років. Бібліотечний вісник. 5:3-10

[8] Ali, M, Loan, FA, Mushatq, R. 2018. Open Access Scientific Digital Repositories An Analytical Study of the Open DOAR. Ieee 5th international symposium on emerging trends and technologies in libraries and information services (ettlis 2018) /ed.Kataria, S; Anbu, KJP; Gartner, R; Sandhu, G. 213-216.

[9] De Silva, PUK, Vance, CK. 2017. On the Road to Unrestricted Access to Scientific Information: The Open Access Movement. Scientific scholarly communication: the changing landscape. 25-40. https://doi.org/10.1007/ 978-3-319-50627-2_3.

[10] Landoy, A., Ghinculov, S., Repanovici, A., Cheradi, N. 2016. Open Access policies and experiences in Norway, Romania and Moldova. Qualitative Gamp; quantitative methods in libraries. 643-651.

[11] Martin-Martin, A., Costas, R., van Leeuwen, T., Lopez-Cozar, ED. 2018. Evidence of open access of scientific publications in Google Scholar: A largescale analysis. Journal of informetrics 12(3):819:841. https://doi.org/10. 1016/j.joi.2018.06.0612.

[12] Schopfel, J., Ferrant, C., Andre, F., Fabre, R. 2016. Ready for the future? A survey on open access with scientists from the French National Research Center (CNRS). Interlending \&amp; document supply. 44(4):141-149. https://doi.org/10.1108/ILDS-06-2016-0023.

\section{Referenses}

[1] Bolkotun, Z.A., Radchenko A.I. 2019. Naukovyi zhurnal - vyklyky sohodennia. IKh Naukovo-praktychna konferentsiia «Naukova periodyka: tradytsii ta innovatsii» Visnyk NAN Ukrainy. 7:89-94. https://doi.org/ $10.15407 /$ visn2019.07.089.

[2] Vse ukrainskiye zhurnaly v Scopus i Web of Science Open Science in Ukraine (OSU) https://openscience.in.ua/ua-journals.

[3] Kaminska, A.M., Nazarovets S.A. 2018. Crossreff yak dzherelo nauko metrychnykh danykh dlia sotsialnykh ta humanitarnykh nauk. Suchasnyi stan naukovykh doslidzhen ta tekhnolohii v promyslovosti. 3 (5):26-34. https://doi.org/10.30837/2522-9818.2018.5.026.

[4] Perelik naukovykh fakhovykh vydan Ukrainy, v yakykh mozhut publikuvatysia rezultaty dysertatsiinykh robit na zdobuttia naukovykh stupeniv doktora i kandydata nauk (stanom na 11 lypnia 2019 roku) Naukovi fakhovi vydannia. Ministerstvo osvity i nauky Ukrainy. https://mon.gov. ua/ua/nauka/nauka/atestaciya-kadriv-vishoyi-kvalifikaciyi/naukovi-faho vi-vidannya. 
[5] Pro zatverdzhennia Poriadku formuvannia Pereliku naukovykh fakhovykh vydan Ukrainy Nakaz MON Ukrainy vid 15.01.2018 № 32 https://zakon. rada.gov.ua/laws/show/z0148--18.

[6] Iaroshenko, T.O. 2010. Elektronni zhurnaly v systemi informatsiinykh resursiv biblioteky. Kyiv : Znannia.

[7] Iaroshenko T. 2011 Zelenyi shliakh vidkrytoho dostupu. Repozytarii taikh rol u naukovii komunikatsii: pershi dvadtsiat rokiv. Bibliotechnyi visnyk. $5: 3-10$

[8] Ali, M, Loan, FA, Mushatq, R. 2018. Open Access Scientific Digital Repositories An Analytical Study of the Open DOAR. Ieee 5th international symposium on emerging trends and technologies in libraries and information services (ettlis 2018) /ed.Kataria, S; Anbu, KJP; Gartner, R; Sandhu, G. 213-216.

[9] De Silva, PUK, Vance, CK. 2017. On the Road to Unrestricted Access to Scientific Information: The Open Access Movement. Scientific scholarly communication: the changing landscape. 25-40. https://doi.org/10.1007/ 978-3-319-50627-2_3.

[10] Landoy, A., Ghinculov, S., Repanovici, A., Cheradi, N. 2016. Open Access policies and experiences in Norway, Romania and Moldova. Qualitative Gamp; quantitative methods in libraries. 643-651.

[11] Martin-Martin, A., Costas, R., van Leeuwen, T., Lopez-Cozar, ED. 2018. Evidence of open access of scientific publications in Google Scholar: A largescale analysis. Journal of informetrics 12(3):819:841 https://doi.org/10. 1016/j.joi.2018.06.012.

[12] Schopfel, J., Ferrant, C., Andre, F., Fabre, R. 2016. Ready for the future? A survey on open access with scientists from the French National Research Center (CNRS). Interlending \&amp; document supply. 44(4):141-149. https://doi.org/10.1108/ILDS-06-2016-0023. 